\title{
On the control of secondary carbanion structure utilising ligand effects during directed metallation
}

\author{
Andrew E. H. Wheatley ${ }^{* 1}$, Jonathan Clayden ${ }^{2}$, Ian H. Hillier ${ }^{2}$, \\ Alison Campbell Smith ${ }^{1}$, Mark A. Vincent ${ }^{2}$, Laurence J. Taylor ${ }^{1}$ \\ and Joanna Haywood ${ }^{1}$
}

\author{
Full Research Paper \\ Address: \\ ${ }^{1}$ Department of Chemistry, University of Cambridge, Lensfield Road, \\ Cambridge, CB2 1EW, UK and ${ }^{2}$ School of Chemistry, University of \\ Manchester, Oxford Road, Manchester, M13 9PL, UK \\ Email: \\ Andrew E. H. Wheatley - aehw2@cam.ac.uk \\ * Corresponding author \\ Keywords: \\ directed metallation; Lewis base; ligand effects; lithium; secondary \\ carbanion
}

Open Access

\author{
Beilstein J. Org. Chem. 2012, 8, 50-60. \\ doi:10.3762/bjoc. 8.5 \\ Received: 14 September 2011 \\ Accepted: 15 December 2011 \\ Published: 09 January 2012 \\ This article is part of the Thematic Series "Directed aromatic \\ functionalization". \\ Guest Editor: V. Snieckus \\ (C) 2012 Wheatley et al; licensee Beilstein-Institut. \\ License and terms: see end of document.
}

\begin{abstract}
$N, N$-Diisopropyl-2-propylbenzamide 6-H undergoes lateral deprotonation by $t$-BuLi in the presence of the Lewis base PMDTA $\left(N, N, N^{\prime}, N^{\prime \prime}, N^{\prime \prime}\right.$-pentamethyldiethylenetriamine) to give a benzyllithium 6-Lil PMDTA that incorporates a trigonal planar secondary carbanion. In the solid state, the amide directing group and the PMDTA additive work together to abstract the metal ion from the deprotonated $\alpha$-C of the propyl group (4.107(4) $\AA$ ). A short distance of 1.376(3) $\AA$ is observed between the deprotonated carbon centre and a planar aromatic system that shows a pattern of bond lengths which contrasts with that reported for related tertiary carbanion systems. Analogous benzylic deprotonation is seen if $6-\mathrm{H}$ is treated with $t$-BuLi in the presence of diglyme to give 6-Lil DGME. X-ray crystallography now shows that the metal ion more closely approaches the tertiary carbanion (2.418(6) $\AA$ ) but that the planarity of the deprotonated carbon centre and the bonding pattern in the organic anion seen in the PMDTA complex are retained. DFT analysis corroborates both the short distance between aromatic ring and carbanion centre and the unperturbed nature of aromaticity in 6- $\mathrm{Li}_{l} \cdot \mathrm{L}$ ( $\mathrm{L}=$ Lewis base). The observation of two structure-types for the carbanion in solution is explained theoretically and by NMR spectroscopy in terms of cis and trans isomerism imparted by partial double bond character in the arene- $(\alpha-C)$ bond.
\end{abstract}

\section{Introduction}

Directed deprotonative lithiation - where the directing group generally combines inductive electron withdrawal with the presence of an electron-rich metal-coordinating atom [1] - has established itself as an enormously powerful tool for the elabor- ation of aromatic and heteroaromatic compounds [2-9] and continues to find new applications today [10,11]. Various highly selective aryl $\mathrm{C}-\mathrm{H}$ deprotonative metallations have been reported because of the directing group's ability to inductively 
raise hydrogen atom acidity and because the incoming organometallic reagent closely approaches the reactive position ("ortho lithiation" when deprotonation occurs adjacent to the directing group $[2,3]$, "directed remote metallation" when reaction is nonadjacent [12-15]).

However, the presence of substituents at the ortho position of the aromatic ring introduces the possibility of deprotonating the substituent at the benzylic (or $\alpha$-) position ("lateral lithiation") through the directing group coordinating the incoming organometallic substrate whilst conjugatively withdrawing electrons from the benzylic group [2]. In the case of lateral reaction, stabilisation of the resulting anion is expected to favour benzylic deprotonation when reactions are potentially competitive $[16,17]$. However, in practice, the exact nature of the lateral group may complicate matters. For example, the presence of a heteroatom at the $\beta$-position of the lateral group may either promote or retard lateral deprotonation on electronic grounds $[1,2]$. Moreover, steric effects have also been found to play an important role. Hence, whereas the formation of primary [18] and secondary [19] carbanions through lateral deprotonation has been known for many years, it is only very recently that the analogous formation of tertiary carbanions has been reported [20].

Amongst the most important, versatile and widely used agents for directing the deprotonative lithiation of aromatic substrates are amide type (or " $\mathrm{N}+\mathrm{O}$ ") groups [3]. In the case of such systems, solid-state structural evidence for carbanion structure has only emerged in the last decade or so. These data focused on reactions directed by tertiary amides; with the ortho metallation of $N, N$-diisopropylbenzamide $\mathbf{1 - H}$ and its naphthamide analogue 2-H [21] giving species that have been characterised as solid-state dimers. These metallo-intermediates are each based on a $(\mathrm{CLi})_{2}$ core wherein each metal ion is further stabilised by one solvent molecule ( $\mathrm{OEt}_{2}$ or THF, Scheme 1) and an amide O-centre through modulation of the amide-arene twist angle (documented as being near perpendicular in the corresponding arylamide substrates [22]).

More recently, the focus has shifted towards the study of the competition between the ortho and lateral deprotonation of 2-alkylated benzamide substrates. Hence, 2-ethylated analogues of 1-H and 2-H (3-H and 4-H, respectively; Scheme 2) have been treated with $t$-BuLi in the presence of either PMDTA $\left(N, N, N^{\prime}, N^{\prime \prime}, N^{\prime \prime}\right.$-pentamethyldiethylenetriamine) (for 3-H) [23] or THF (for 4-H) [24] to yield 3/4-Li $l \cdot n \mathrm{~L}$ ( $n=1, \mathrm{~L}=$ PMDTA; $n=$ $3, \mathrm{~L}=\mathrm{THF}$ ). Notably, whereas the deptonation of $4-\mathrm{H}$ in the presence of THF yielded the lateral lithiate as a tris(THF) solvate, the tridentate electron donor PMDTA was required to replicate this chemistry with $\mathbf{3}-\mathrm{H}$. Attempts to utilise THF in

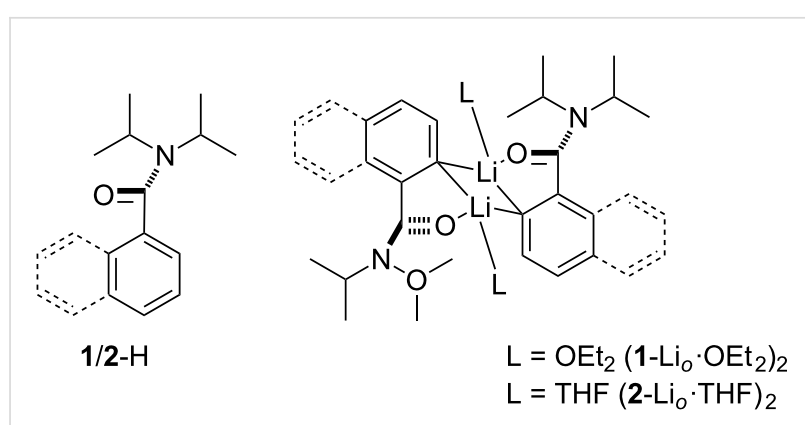

Scheme 1: Molecular structures of $\mathbf{1 / 2}-\mathrm{H}$ and their corresponding ortho-lithiates [21].

this last system resulted, instead, in the isolation and characterisation of ortho metallated $3-\mathrm{Li}_{o} \cdot \mathrm{THF}$, the solid-state structure of which revealed a dimeric structure analogous to those seen for $\mathbf{1}-\mathrm{Li}_{o} \cdot \mathrm{THF}$ and $\mathbf{2}-\mathrm{Li}_{o} \cdot \mathrm{THF}$ [21]. It was subsequently established that the conversion of this (kinetic) lithiate into the thermodynamic (lateral) species could be observed in solution spectroscopically (Scheme 3) [23].

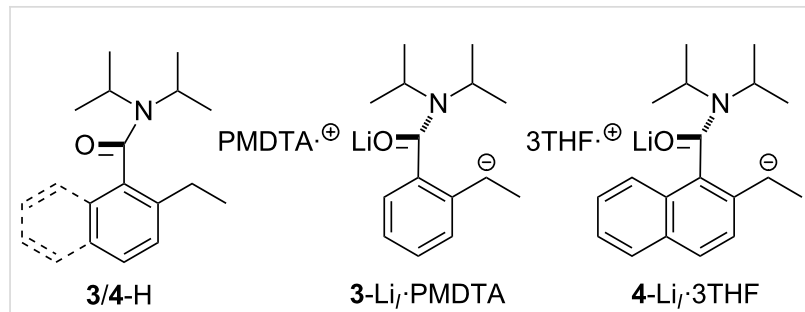

Scheme 2: Molecular structures of $\mathbf{3} / \mathbf{4}-\mathrm{H}$ and their corresponding lateral lithiates $[23,24]$.

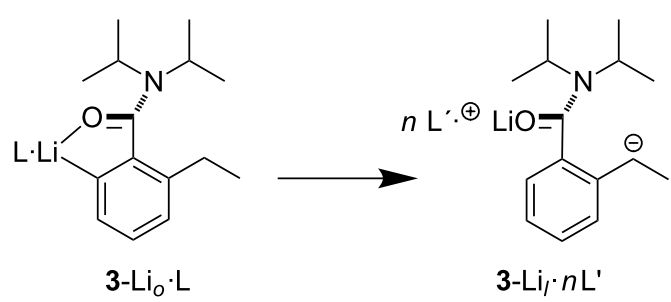

Scheme 3: Conversion of kinetic ortho-lithiate into the thermodynamic lateral lithiate under the influence of strong $\left(\mathrm{L}=\mathrm{THF}, n=1, \mathrm{~L}^{\prime}=\right.$ PMDTA) or excess (e.g., $L=L^{\prime}=$ THF,$n>1$ ) Lewis base [23].

The need to utilise multidentate donors in place of monodentate solvents such as $\mathrm{OEt}_{2}$ or THF to incur the lateral deprotonation of 2-alkylated arylamides in which the 6-position is not blocked (contrast this scenario with the conversion of 4-H into 4-Li $l^{3} 3 \mathrm{THF}$ ) recently led us to examine the hitherto unachievable formation of tertiary carbanions by directed lateral lithiation [16,17]. Accordingly, 2-isopropyl- $N, N$-diisopropylbenz- 


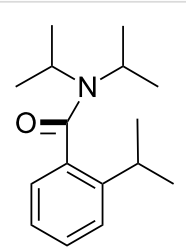

5- $\mathrm{H}$

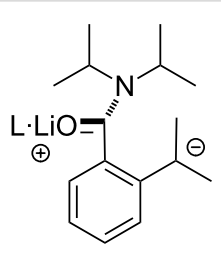

$L=P M D T A, D G M E$ 5-Li, $\cdot L$<smiles>CCOc1cccc(C(C)C)c1C(=O)N(C(C)C)C(C)C</smiles>

$\left(5-\mathrm{Li}_{o}\right)_{2} \cdot \mathrm{OEt}_{2}$

Scheme 4: Molecular structure of 5-H and its lateral and ortho-lithiates [20].

amide $(\mathbf{5}-\mathrm{H})$ has been used to source $5-\mathrm{Li} l \cdot \mathrm{L}(\mathrm{L}=$ PMDTA, DGME; DGME = diglyme) and also, under kinetic control, the remarkable hemi-solvated ortho-lithiate (Scheme 4). This development allowed thermodynamic lithiate $\mathbf{5}-\mathrm{Li}_{l} \cdot \mathrm{PMDTA}$ to be successfully used to generate a variety of benzamides bearing quaternary $\mathrm{C}$-centres at the aromatic 2-position [20].

In this work, we revisit the formation of secondary carbanions, reporting variously solvated lateral lithiates of $\mathrm{N}, \mathrm{N}$-diisopropyl2-propylbenzamide 6-H. We had previously prepared this compound as part of a study of the conformational stability and lability of tertiary aromatic amides bearing a single ortho substituent [25]. At ambient temperature, amides with this substitution pattern are conformationally mobile about their aryl-CO bond [26] on a timescale of seconds or less, and hence, inseparable into atropisomers [27]. However, at the temperatures commonly used to effect lithiation reactions, they should exist as chiral, racemic atropisomers. The stepwise lateral ethylation/ortho methylation of 3-H and lateral methylation/ortho methylation of 6-H [17] prior to warming returned conformationally rigid but oppositely configured amides with diastereomeric ratios $>9: 1$; establishing that reaction was kinetically controlled [28]. Present structural studies of lateral lithiates of 6-H reveal extensive charge delocalisation from a trigonal planar carbanion centre; the displacement of the metal from which is strongly solvent dependent (Scheme 5). Moreover, the improved quality of the crystallographic data for $6-\mathrm{Li}_{l} \mathrm{~L}$ relative to that achievable for $3-\mathrm{Li}_{l}$ PMDTA reveals significant structural parameters that are not available from the previously characterised secondary carbanion [23].

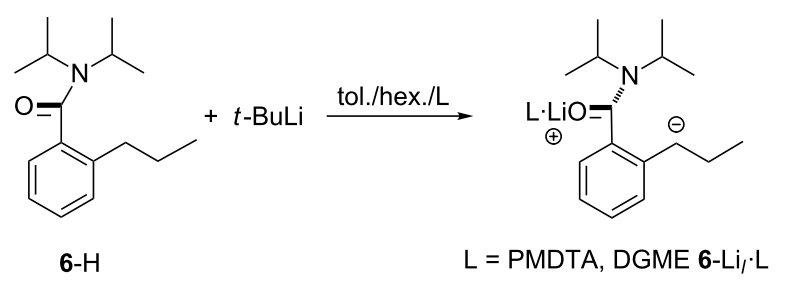

Scheme 5: Lateral metallation of $6-\mathrm{H}$ using $t$-BuLi in the presence of Lewis base $L$.

\section{Results and Discussion \\ Solid-state structural studies}

Based on our knowledge of the ability of Lewis base solvent or additives to influence the chemoselectivity of lithiation, 6-H was treated at $-78{ }^{\circ} \mathrm{C}$ with $t$-BuLi in a hydrocarbon medium to which 1 equiv of PMDTA had been added. The resulting dark purple solution was transferred directly to a freezer $\left(-30^{\circ} \mathrm{C}\right)$ whereupon storage afforded a product that X-ray crystallography revealed to be benzylically deprotonated 6-Li $l \cdot \mathrm{PMDTA}$; in which the metal is encapsulated by the amide oxygen atom and the three donor sites of PMDTA (Scheme 5, Figure 1 and Supporting Information File 1). Importantly, the use of a Pr substituent (cf. 2-Et in 3-H) obviates the crystallographic disorder that limited the analysis of the structure of 3-Li $r$ PMDTA by preventing the anisotropic refinement of both the aromatic ring and the deprotonated alkyl chain [23]. In fact, the direct observation of $\mathrm{H} 8$ by Fourier difference synthesis $[29,30]$ and the anisotropic refinement of this atom allows an exact understanding of the geometry at the carbanion centre: In

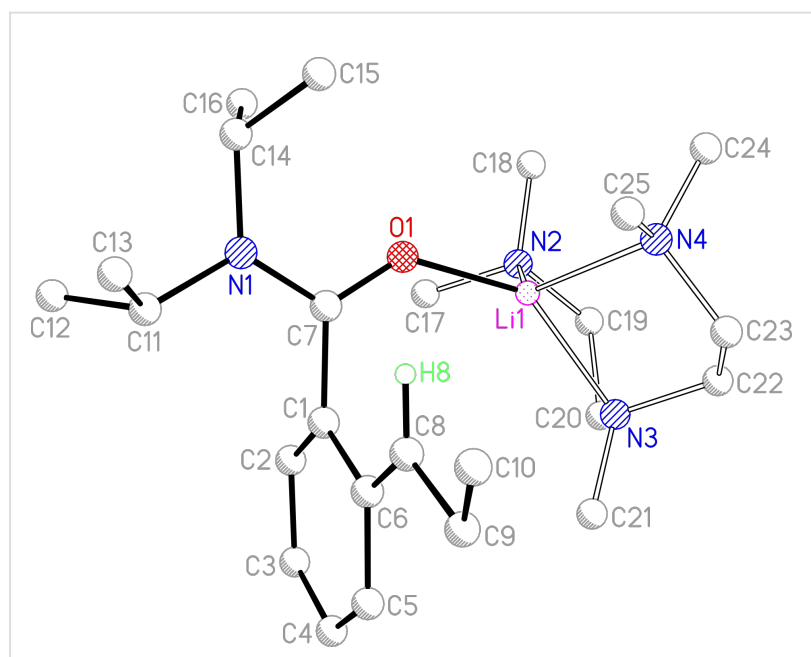

Figure 1: Molecular structure of 6-Li/PMDTA; $\mathrm{H}$-atoms (excl. H8) omitted for clarity. Selected bond lengths $(\AA)$ and angles $\left({ }^{\circ}\right)$ : O1-Li1 1.845(3), N2-Li1 2.116(4), N3-Li1 2.097(3), N4-Li1 2.123(4), C8 ․Li1 4.107(4), C8-H8 0.957(19), C8-C9 1.497(3), C9-C10 1.510(3), C8-C6 1.376(3), C6-C5 1.450(3), C5-C4 1.371(3), C4-C3 1.371(3), C3-C2 1.405(3), C2-C1 1.372(3), C1-C6 1.446(3), C6-C1-C7-O1 88.4(2), C7-C1-C6-C8 6.1(3). 
6-Li $l \cdot$ PMDTA amide coordination and solvation by PMDTA have worked together to displace the $\mathrm{Li}^{+}$ion from deprotonated $\mathrm{C} 8$, resulting in an essentially flat secondary carbanion (C6-C8-C9 125.0(2) ${ }^{\circ}, \mathrm{C} 6-\mathrm{C} 8-\mathrm{H} 8$ 120.9(11) ${ }^{\circ}, \mathrm{C} 9-\mathrm{C} 8-\mathrm{H} 8$ $\left.114.0(11)^{\circ}\right)$.

Akin to the recently reported structure of $5-\mathrm{Li}_{l} \cdot \mathrm{PMDTA}$, a short arene- $(\alpha-\mathrm{C})$ bond is noted in $6-\mathrm{Li}_{l}$ PMDTA $(1.376(3) \AA)$. However, whereas the amide-arene orientation in a laterally lithiated tertiary aromatic amide has previously approximated to $80^{\circ}$ in the presence of a secondary benzylic carbanion (viz. $\mathrm{C}(\mathrm{CLi})-\mathrm{C}-\mathrm{C}-\mathrm{O} 79.2(4)^{\circ}$ in $3-\mathrm{Li}_{l} \cdot$ PMDTA [23], 82.5(5) ${ }^{\circ}$ in 4-Li $l^{3}$ THF [24]) and has been significantly reduced (to 42.8(3) and 39.7(2) in 5- $\mathrm{Li}_{l} \cdot \mathrm{L}$ (L = PMDTA, DGME) [20]) in the presence of a tertiary benzylic carbanion, that in $6-\mathrm{Li}_{l}$ :PMDTA is higher (C6-C1-C7-O1 88.4(2) $)^{\circ}$, plainly precluding any azaenolate contribution to anion stability (C7-C1 1.493(3) Å). Moreover, though the analysis of charge delocalisation has recently been undertaken for benzylic tertiary carbanions, revealing a pentadienyl bonding pattern with alternating short and long bonds noted between the deprotonated $(\alpha-C)$ and the aromatic carbon centre para to it, the situation for secondary carbanionic 6-Li ${ }_{l}$ PMDTA is different. This could not be ascertained for previously reported $3-\mathrm{Li}_{l}$-PMDTA [23], where crystallographic disorder meant that both the arene- $(\alpha-C)$ interaction and bonds within the aromatic ring were constrained. In the present case, both aromatic and lateral group carbon atoms could be refined freely, allowing us to compare bond lengths in tert-carbanion 5-Li ${ }_{l}$ PMDTA and $s e c$-carbanion 6-Li ${ }_{l}$ PMDTA in Scheme 6. It is clear that bond-length alternation seen in 5-Li $l_{l}$ PMDTA (where the carbanion is best viewed as exhibiting pentadienyl character) is not replicated in 6 - $\mathrm{Li}_{l}$ PMDTA. Instead, combined with the planarity of the ring system observed here, bond lengths in 6-Li $l_{l}$ PMDTA suggest the retention of aromaticity. Consistent with this, a torsion of only $6.1(3)^{\circ}$ between directing and deprotonated groups $(\mathrm{C}(=\mathrm{O})-\mathrm{C}-\mathrm{C}-\mathrm{C}(\mathrm{Li}))$ in $6-\mathrm{Li}_{l}$ PMDTA contrasts with one of $32.6^{\circ}$ in $5-\mathrm{Li}_{l} \cdot \mathrm{PMDTA}$. The behaviour of the present system therefore contrasts with that reported previously for benzylically deprotonated analogues. Thus, benzyl anions [31-43] including amino- [44-46], phosphino- [47-49], thio-/sulfamido-/ sulfimido- [50-53] and silylbenzyl anions [54-62], have all demonstrated long aryl- $(\alpha-C)$ distances $(1.419-1.538 \AA)$ with retention of aromaticity. In contrast, 5 - $\mathrm{Li}_{l} \cdot$ PMDTA and laterally lithiated $N$-trimethylsilyl $o$-methylphenyldiphenylphosphinimine [63] demonstrated a short aryl-( $\alpha-C)$ distance (of 1.376(6) $\AA$ in both cases $[20,63])$ in tandem with a pentadienyl bonding pattern and significant perturbation of the aryl system. Uniquely, the secondary carbanion in 6-Lil ${ }_{l}$ PMDTA shows both a short aryl- $(\alpha-C)$ distance and the significant retention of aromaticity.

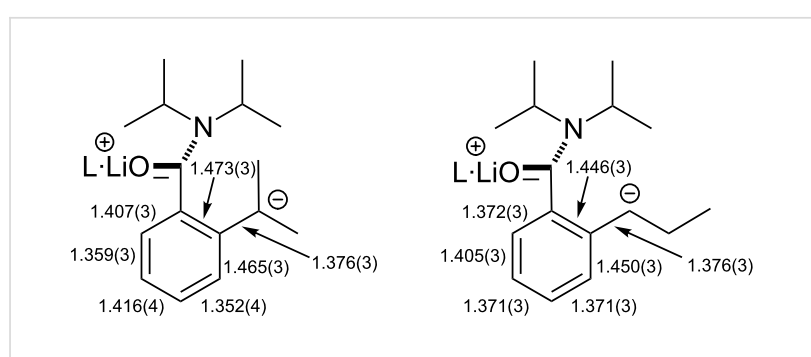

Scheme 6: Comparison of aromatic and aryl- $(\alpha-C)$ bond distances in 5-Li, L [20] and 6-Li, L (L = PMDTA).

Similar charge delocalisation effects to those seen in 6-Li $l$-PMDTA are present in 6-Li $l$ DGME (Scheme 5, Figure 2 and Supporting Information File 2). Hence, the metal is wrapped by the amide and DGME oxygen atoms. Consistent with the view that oxygen is an inferior donor as compared with nitrogen (in PMDTA) and that DGME is a less sterically congesting donor additive than PMDTA, the solid-state structure of 6-Li $l$ DGME allows a significantly shorter $(\alpha-\mathrm{C}) \cdots$ Li distance of $2.418(6) \AA$. As was seen, however, for tertiary carbanion systems, the close approach of these two atoms need not incur any significant reorganisation of the geometry at $\mathrm{C} 8$, with both $\mathrm{C} 8$ and $\mathrm{C} 9$ lying essentially in the aromatic ring plane and the C6-C8-C9 bond angle of $124.9(3)^{\circ}$ suggesting an essentially trigonal planar $\mathrm{sp}^{2}$-hybridised carbanion. Akin to the short aryl- $(\alpha-\mathrm{C})$ distance in 6-Li $l$ PMDTA, that in the diglyme analogue is $1.377(5) \AA$. However, a point of significant contrast between the structures of 6-Lil $\mathrm{L}$ DGME and its PMDTA analogue is the $\mathrm{C} 6-\mathrm{C} 1-\mathrm{C} 7-\mathrm{O} 1$ torsional angle. Whereas this

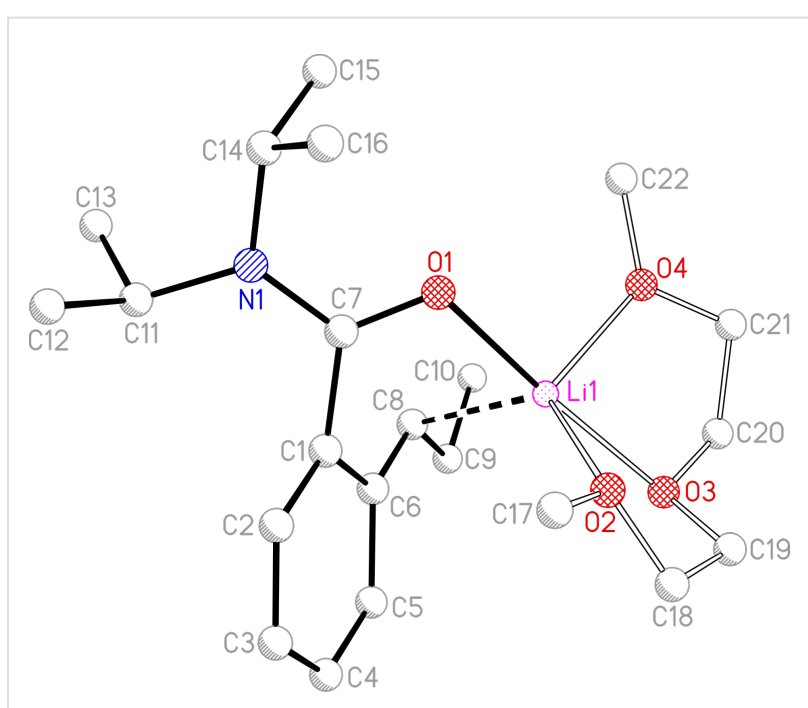

Figure 2: Molecular structure of 6-Li, DGME; H-atoms omitted. Selected bond lengths $(\AA)$ and angles $\left({ }^{\circ}\right)$ : O1-Li1 2.001(6), O2-Li1

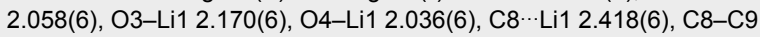
1.478(5), C9-C10 1.511(6), C8-C6 1.377(5), C6-C5 1.445(5), C5-C4 1.365(5), C4-C3 1.387(6), C3-C2 1.389(5), C2-C1 1.382(5), C1-C6 1.448(5), C6-C1-C7-O1 54.2(4), C7-C1-C6-C8 12.2(5). 
was $88.4(2)^{\circ}$ in the latter complex and $>80^{\circ}$ in each of the previously reported secondary carbanion systems $4-\mathrm{Li}_{l} \cdot 3 \mathrm{THF}$ [24] and 3-Li $l_{l}$ PMDTA [23], the $(\alpha-\mathrm{C}) \cdots \mathrm{Li}$ interaction in 6- $\mathrm{Li}_{l}$ DGME reduces the torsional angle to only $54.2(4)^{\circ}$. In spite of this, at 1.485(5) $\AA$ the arene-directing group interaction is still long - arguing against any azaenolate contribution to anion stability.

\section{NMR spectroscopic studies}

NMR spectroscopic investigation of $6-\mathrm{Li}_{l}$ PMDTA in $\left[\mathrm{D}_{8}\right]$ toluene solution reveals that dissolution affords multiple solution species. Limited reformation of the starting material 6-H is observed (species \#3, see Experimental section). This phenomenon has been seen in previous solution studies of the lateral metallates of aromatic tertiary amides [23] and is assumed to reflect the sensitivity of $6-\mathrm{Li}_{l}$-PMDTA to traces of moisture in the deuterated solvent. However, in contrast to previous work, two forms of lateral metallate (\#1 and \#2, see Experimental section) are clearly seen. Based on previous work on the 4-Li $\mathrm{i}_{l}$ system [64], we consider these two species to represent the cis and trans isomers of $6-\mathrm{Li}_{l}$ that arise from slow rotation about the partially double arene- $(\alpha-C)$ bond in the PMDTA-solvated lithiate. The isomers exist in temperature independent major and minor forms, with the trans isomer assumed to dominate on steric grounds and the ratio between species approximating to 10:1:1 (\#1:\#2:\#3). This can be clearly seen in the signals associated with the lateral alkyl chain, with a triplet and double doublet seen for the deprotonated methylene at $\delta 3.10(\# 1)$ and $3.22(\# 2)$ ppm, respectively, with $6-\mathrm{H}$ revealing a concomitant multiplet at $\delta 2.71-2.60 \mathrm{ppm}$. Consistent with the observation of essentially trigonal planar geometry at $\mathrm{C} 8$ in the solid-state structure of $6-\mathrm{Li}_{l}$ PMDTA (Figure 1), both solution isomers reveal significantly deshielded deprotonated carbon centres. Hence, observed shifts of $\delta 67.1$ (\#1) and 71.9 (\#2) ppm contrast with that of $\delta 35.3$ ppm for the corresponding tetrahedral $\alpha-\mathrm{C}$ in $6-\mathrm{H}$. Although depletion of aromaticity was noted in the recently reported solid-state structure of tertiary carbanion $5-\mathrm{Li}_{l}$ PMDTA, the character of the aromatic system in solution was less clear cut. While high-field aromatic signals (in the range of $\delta 6.94-5.78 \mathrm{ppm}$ ) were seen, computational studies suggested the close approach of the carbanionic centre and the metal, implying a more localised anionic charge in solution [20]. In the present case, the solid-state structure of $6-\mathrm{Li}_{l} \cdot$ PMDTA reveals the clear retention of aromatic character and, in this context, it is noteworthy that ${ }^{1} \mathrm{H}$ NMR spectroscopic resonances of $\delta 6.90-5.58$ (in major isomer \#1) and 6.73-5.77 (in minor isomer \#2) ppm compare closely with those seen for $\mathbf{5}-\mathrm{Li}_{l}$ PMDTA.

Just as ${ }^{1} \mathrm{H}$ NMR spectroscopy yields evidence for two lithiate structures in solution - in a ratio approximating to $10: 1-$
${ }^{1} \mathrm{H},{ }^{7} \mathrm{Li}-\mathrm{HOESY}[65]$ reveals correlations between the major $\mathrm{Li}$ peak $(\delta 0.51 \mathrm{ppm})$ and ${ }^{1} \mathrm{H}$ signals which, at $\delta 3.10$ (strong correlation), 2.08 (moderate) and $6.36 \mathrm{ppm}$ (weak), represent the benzylic hydrogen atom, the central Me group of PMDTA and the ortho hydrogen atom, respectively (see Supporting Information File 3). An analysis of the corresponding throughspace displacements in the solid-state structure of 6-Lil $\mathrm{PMDTA}^{\mathrm{P}}$ reveals $\mathrm{H}$ (benzylic) $\cdots \mathrm{Li}$ and $\mathrm{H}(\text { ortho })^{\cdots} \mathrm{Li}$ (3.894(18) and 3.974(17) $\AA$, respectively, viz. C8, C2) in the range expected to permit the observation of nOes [66]. This and theoretical results ([20] and see below) serve to reinforce the view that the dominant solution form of 6 - $\mathrm{Li}_{l} \cdot$ PMDTA closely resembles the structure observed in the solid state insofar as the disposition of the partial double arene- $(\alpha-C)$ bond is trans. While the solidstate structure of 6 - $\mathrm{Li}_{l} \cdot$ PMDTA also suggests the possibility of through-space interactions between the metal and $\mathrm{NCHMe}$ groups (viz. C15, C16), the well established dynamic behaviour of these latter groups [67] provides a rationale for the lack of associated nOes here. Similarly, the central PMDTA Me group (viz. $\mathrm{C} 21$ ) resides such that the associated hydrogen atoms are located 3-4 $\AA$ from the metal to which they reveal a HOESY correlation. However, while the terminal Me groups (viz. C17, $\mathrm{C} 18, \mathrm{C} 24, \mathrm{C} 25)$ of the Lewis base also lie $<4 \AA$ from the metal, the lack of an associated correlation is consistent with greater dynamic activity. Lastly, the proposed model is consistent with the observation that the minor Li signal ( $\delta 0.15 \mathrm{ppm})$ correlates only with the central PMDTA Me resonance at $\delta 2.08 \mathrm{ppm}$. Cis6- $\mathrm{Li}_{l} \cdot$ PMDTA might be expected to reveal a correlation between $\mathrm{Li}^{+}$and the $\beta$-hydrogen atoms of the deprotonated propyl group. However, both the low population of this species and the significant dynamic activity exhibited by the $\beta$-hydrogen atoms in solution - as evidenced by ${ }^{1} \mathrm{H}$ NMR spcectroscopy - significantly diminish the likelihood of observing such a correlation (see Supporting Information File 3).

The study of $6-\mathrm{Li}_{l} \cdot \mathrm{DGME}$ in $\left[\mathrm{D}_{8}\right]$ toluene by NMR spectroscopy reveals data comparable to that seen for the PMDTA system. In spite of the deployment of a Na mirror to dry the deuterated solvent, significant reformation of 6-H is observed (species \#3, see Experimental section) suggesting that the 6-Li $l_{l}$ DGME is highly solvent- and temperature-sensitive. The presence of hydrolyzed 6- $\mathrm{H}$ is clear from the observation of the aliphatic region of the spectrum. Thus, the signals associated with the lateral alkyl chain in 6 - $\mathrm{H}$ reveal a multiplet $(\delta$ $2.69-2.58 \mathrm{ppm})$ for the $\alpha-\mathrm{CH}_{2}$, two multiplets $(\delta 1.79,1.62$ ppm) for the $\beta-\mathrm{CH}_{2}$ and a triplet ( $\left.\delta 0.97 \mathrm{ppm}\right)$ for Me. However, COSY reveals a laterally deprotonated species (\#1) that expresses signals at $\delta 3.05(\alpha-\mathrm{CH}), 2.35\left(\beta-\mathrm{CH}_{2}\right)$ and $1.36 \mathrm{ppm}$ (Me). Comparable with what was seen for $6-\mathrm{Li}_{l} \cdot \mathrm{PMDTA}$, the essentially trigonal planar geometry at $\mathrm{C} 8$ in the solid-state 
structure of 6-Li ${ }_{l}$ DGME appears to be reflected in solution, with a ${ }^{13} \mathrm{C}$ NMR shift of $\delta 64.6 \mathrm{ppm}(\alpha-\mathrm{CH}, \# 1$, cf. $\delta 67.1 \mathrm{ppm}$ for the major isomer of 6-Lil $\mathrm{PMDTA}^{\mathrm{P}}$ ) contrasting with that of $\delta 35.3 \mathrm{ppm}\left(\alpha-\mathrm{CH}_{2}, \# 3\right)$. Lastly, the co-existence of two temperature-independent isomers of lateral lithiate (major \#1, minor \#2) can still be seen for the DGME system (see Experimental section). However, owing to the complexity of the spectra, the minor metallated form only expresses clear signals in the aromatic region of the ${ }^{1} \mathrm{H}$ NMR spectrum. An analysis of this reveals that the ratio between the three species approximates to 1:0.15:3 (\#1:\#2:\#3). Hence, COSY correlations reveal signals at $\delta 7.13-7.00 \mathrm{ppm}$ for $6-\mathrm{H}$, at $\delta 6.88(1 \mathrm{H}), 6.46(1 \mathrm{H})$, $6.38(1 \mathrm{H}), 5.63(1 \mathrm{H}) \mathrm{ppm}$ for the dominant lithiate, and at $\delta$ $6.74(0.15 \mathrm{H}), 6.63(0.3 \mathrm{H}), 5.69(0.15 \mathrm{H}) \mathrm{ppm}$ for the minor lithiate.
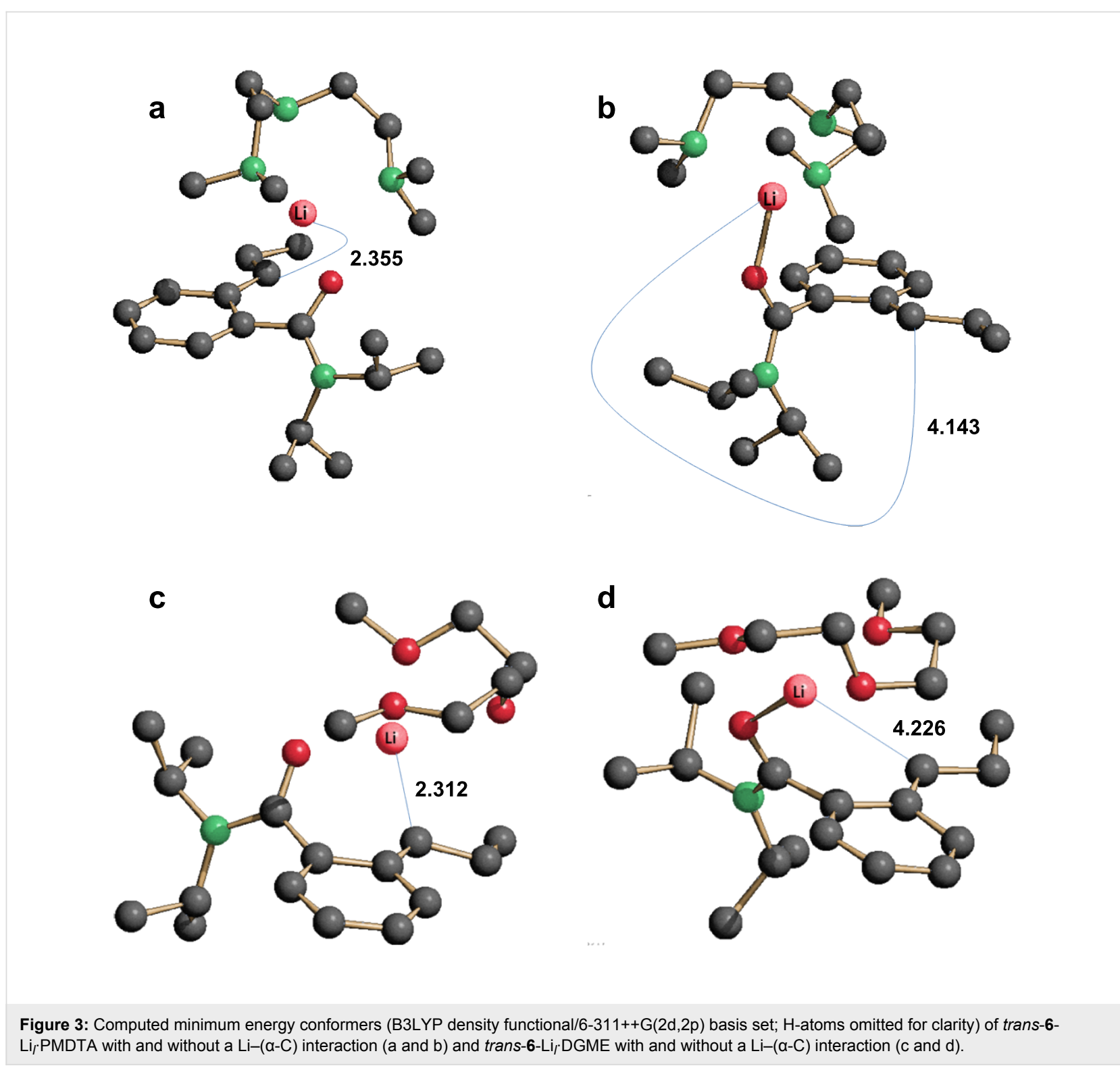

\section{Computational studies}

The structures of 6-Li $l \cdot \mathrm{L}$ ( $\mathrm{L}=$ PMDTA, DGME) were optimised using density functional theory (DFT) calculations. For the use of either Lewis base, two isomeric forms of $6-\mathrm{Li}_{l}$ were modelled. These were the cis and trans isomers expected to arise from slow rotation about the partially double arene- $(\alpha-C)$ bond (see above). For each Lewis base, calculation of the trans isomer identified two minimum energy structures with very different $\mathrm{Li}-\mathrm{C}$ (carbanion) distances. In the case of 6-Li $\mathrm{L}_{l}$-PMDTA these distances were 2.355 and $4.143 \AA$ (Figure $3 \mathrm{a}$ and Figure $3 \mathrm{~b}$, respectively). The structure having the longer distance is found to be more stable by $2.6 \mathrm{kcal} \cdot \mathrm{mol}^{-1}$, this distance being close to the experimental value (4.107(4) $\AA$ ). It is also possible to compare the measured $\mathrm{C}-\mathrm{C}$ bond lengths in the aromatic ring and the exogenous $\mathrm{C}-\mathrm{C}$ lengths with those 
predicted for the two structures by using the mean unsigned error (MUE) between the calculated and experimentally observed values. We found that the MUEs are 0.010 and $0.017 \AA$ for the PMDTA-complexed structures with the long and short metal-carbon distances, respectively. Thus, in terms of the structure of the unsaturated ring, calculation of trans-6Lil PMDTA favours the type of structure observed experimentally in the solid state.

A similar computational analysis to that undertaken for trans-6$\mathrm{Li}_{l}$ PMDTA also located two structures for trans-6-Lil $\mathrm{P}_{l}$ DGME. However, in this case, the structure having the shorter Li-C(carbanion) distance (2.312 A, Figure $3 \mathrm{c}$ ) was computed to be more stable (by $2.4 \mathrm{kcal} \cdot \mathrm{mol}^{-1}$ ) than that expressing a longer distance (4.226 $\AA$, Figure $3 \mathrm{~d}$ ). This theoretical result is in line with the corresponding distance measured in the solid-state structure (2.418(6) $\AA$ ). Likewise, a comparison between the measured and predicted $\mathrm{C}-\mathrm{C}$ distances involving the aromatic ring gave a similar result with MUE values of 0.009 and $0.010 \AA$ found for the structures having short and long $\mathrm{Li}-\mathrm{C}$ lengths, respectively.

Having computed the most stable trans forms of both the PMDTA and DGME complexes of $\mathbf{6}-\mathrm{Li}_{l}$, the corresponding cis isomers were modelled. These were found to be higher in energy; consistent with the view (see above) that they represent the less populous species in solution. Hence, cis-6-Lil $\mathrm{L}_{l}$ PMDTA and $c i s-6-\mathrm{Li}_{l}$-DGME (see Supporting Information File 3) were $5.4 \mathrm{kcal} \cdot \mathrm{mol}^{-1}$ and $2.2 \mathrm{kcal} \cdot \mathrm{mol}^{-1}$ higher in energy than the minimum energy structures computed for each of trans-6$\mathrm{Li}_{l}$ :PMDTA and trans-6-Li $l \cdot$ DGME, respectively.

\section{Conclusion}

$N, N$-Diisopropyl-2-propylbenzamide 6-H has undergone selective directed lateral metallation in the presence of both PMDTA and DGME (= L) to give the benzyllithium $6-\mathrm{Li}_{l} \cdot \mathrm{L}$. Unlike previous examples of secondary carbanion formation under the influence of an aromatic tertiary amide directing group, the solid-state structure of $6-\mathrm{Li}_{l}$-PMDTA is sufficiently well resolved to reveal (i) the $\mathrm{sp}^{2}$ geometry of the deprotonated $\alpha-\mathrm{C}$ centre, including the location of the remaining hydrogen atom and, (ii) the lengths of the arene- $(\alpha-\mathrm{C})$ bond and those that form the aromatic system. An analysis of the $\mathrm{C}-\mathrm{C}$ bond lengths shows that, in contrast to all previously reported benzylic lithiates, the secondary carbanion in 6-Li $l$ PMDTA shows both a short arene- $(\alpha-C)$ distance as well as a flat, essentially unperturbed aromatic ring. Similar observations pertain for 6-Li $l$ DGME. Whereas these data contrast with those reported recently for structurally authenticated tertiary carbanions, significant similarities are seen insofar as the connectivity of the alkali metal is concerned when changing tridentate Lewis bases.
Thus, whereas 6-Li $\mathrm{L}_{l}$ PMDTA fails to show a $\mathrm{Li}-(\alpha-\mathrm{C})$ interaction in the solid state, in $\mathrm{Li}_{l}$-DGME the corresponding distance $(2.406(6) \AA)$ suggests an interaction with the amide-arene torsional angle reduced accordingly. DFT analysis successfully reproduces both the bonding patterns seen experimentally in the anionic component of $6-\mathrm{Li}_{l} \mathrm{~L}$ and also the varying propensity of the metal for involvement with the formally deportonated C-centre in the presence of different Lewis bases.

In contrast to previous work on carbanion formation in the presence of an aromatic $\mathrm{N}+\mathrm{O}$ directing group, $6-\mathrm{Li} l \cdot \mathrm{L}$ dissolves in hydrocarbon media to reveal two structures in solution. Based on previous work and new DFT studies, we ascribe these as being cis (minor) and trans (major) isomers based on partial double bond character in the arene- $(\alpha-\mathrm{C})$ bond. ${ }^{1} \mathrm{H},{ }^{7} \mathrm{Li}-\mathrm{HOESY}$ on the PMDTA complex supports this view by revealing a correlation between the metal and the remaining benzylic hydrogen atom in this system. However, the observation that this correlation is substantially stronger than that between the metal and the remaining ortho hydrogen centre suggests that the structure of the major solution isomer of $6-\mathrm{Li}_{l} \cdot \mathrm{PMDTA}$ may involve the metal approaching the benzylic position more closely than is seen in the solid-state structure. These data therefore suggest that, as was recently noted for the analogous tertiary carbanion complexes [20], the major form of 6-Li $l_{l}$ PMDTA in solution shows strong similarities to the solidstate structure of $6-\mathrm{Li}_{l}$ DGME.

Further studies will seek to further probe the solution behaviour observed for $6-\mathrm{Li}_{l} \cdot \mathrm{L}$ to better understand the relationship between the identity and structure of the tridentate Lewis base and the propensity of the metal and deprotonated $\alpha-\mathrm{C}$ centre to interact. In particular, tandem theoretical and NMR spectroscopic studies will seek to elucidate whether polydentate Lewis bases may exhibit dynamic and variable hapticity with respect to the lithium ion in solution, potentially leading to the interconversion of different solution structures. Synthetic work will focus on employing the reported lateral metallates synthetically using a range of electrophiles. Of major interest will be the study of how steric encumbrance controls applications, particularly in the field of generating aromatics with chiral substituents at the 2-position.

\section{Experimental}

\section{General synthetic and analytical details}

Reactions and manipulations were carried out under dry $\mathrm{N}_{2}$ using standard double manifold and glove box techniques. Solvents were distilled off from sodium (toluene) or sodiumpotassium amalgam (hexane) immediately before use. PMDTA and DGME were distilled from sodium at reduced pressure and stored over molecular sieves $(4 \AA)$ and $t$-BuLi $(1.7 \mathrm{M}$ in 
pentane) was purchased from Aldrich and used as received. NMR data were collected on a Bruker $500\left(500.20 \mathrm{MHz}\right.$ for ${ }^{1} \mathrm{H}$, 125.80 MHz for ${ }^{13} \mathrm{C}$ and $194.40 \mathrm{MHz}$ for ${ }^{7} \mathrm{Li}$ ) FT NMR spectrometer. Spectra were obtained at $300 \mathrm{~K}$ and chemical shifts are internally referenced to the deuterated solvent and calculated relative to TMS for ${ }^{1} \mathrm{H}$ and $\left\{{ }^{1} \mathrm{H}\right\}{ }^{13} \mathrm{C}$. For ${ }^{7} \mathrm{Li}$ a $\mathrm{LiCl}(1 \mathrm{M}$ in $\mathrm{D}_{2} \mathrm{O}$ ) reference was employed. Chemical shifts are expressed in $\delta \mathrm{ppm}$. $\left[\mathrm{D}_{8}\right]$ toluene was stored under $\mathrm{N}_{2}$ over a $\mathrm{Na}$ mirror. The following abbreviations are used for NMR spectra: $\mathrm{s}=$ singlet, $\mathrm{d}=$ doublet, $\mathrm{t}=$ triplet, sept $=$ septet, $(\mathrm{v}) \mathrm{br}=($ very $)$ broad and $\mathrm{m}=$ multiplet.

\section{General crystallographic details}

Single crystal data were collected using the 'oil drop technique' [68] to mount crystals on a Nonius Kappa-CCD equipped with an Oxford Cryostream low-temperature device. Structures were solved using direct methods [29], with refinement, based on $F^{2}$, by full-matrix least squares [30]. Crystallographic data (excluding structure factors) have been deposited with the Cambridge Crystallographic Data Centre as supplementary publications CCDC-853884 and -853885 . Copies of the data can be obtained free of charge on application to CCDC, 12 Union Road, Cambridge CB2 1EZ, UK (fax: +44 1223 336033; email: deposit@ccdc.cam.ac.uk).

6-H: $N, N$-Diisopropyl-2-propylbenzamide was prepared from $\mathrm{N}, \mathrm{N}$-diisopropylbenzamide using a modified literature method [25]. Yield $1.11 \mathrm{~g} \mathrm{(90 \% );}{ }^{1} \mathrm{H}$ NMR (500 MHz, [D $]$ toluene, 300 K) $\delta 7.13-7.00(\mathrm{~m}, 4 \mathrm{H}, \mathrm{Ar}), 3.54\left(\mathrm{sept},{ }^{3} J(\mathrm{H}, \mathrm{H})=7 \mathrm{~Hz}, 1 \mathrm{H}\right.$, $\mathrm{NCH}), 2.99$ (sept, $\left.{ }^{3} J(\mathrm{H}, \mathrm{H})=7 \mathrm{~Hz}, 1 \mathrm{H}, \mathrm{NCH}\right), 2.73-2.61(\mathrm{~m}$, $\left.2 \mathrm{H}, \mathrm{ArCH}_{2}\right), 1.92-1.80\left(\mathrm{~m}, 1 \mathrm{H}, \mathrm{ArCH}_{2} \mathrm{CH}_{2}\right), 1.70-1.58(\mathrm{~m}$, $\left.1 \mathrm{H}, \mathrm{ArCH}_{2} \mathrm{CH}_{2}\right), 1.66\left(\mathrm{~d},{ }^{3} J(\mathrm{H}, \mathrm{H})=7 \mathrm{~Hz}, 3 \mathrm{H}, \mathrm{NCMe}\right), 1.64(\mathrm{~d}$, $\left.{ }^{3} J(\mathrm{H}, \mathrm{H})=7 \mathrm{~Hz}, 3 \mathrm{H}, \mathrm{NCMe}\right), 1.00\left(\mathrm{~d},{ }^{3} J(\mathrm{H}, \mathrm{H})=7 \mathrm{~Hz}, 3 \mathrm{H}\right.$, $\left.\mathrm{ArCH}_{2} \mathrm{CH}_{2} \mathrm{Me}\right), 0.68\left(\mathrm{~d},{ }^{3} J(\mathrm{H}, \mathrm{H})=7 \mathrm{~Hz}, 6 \mathrm{H}, \mathrm{NCMe}_{2}\right) \mathrm{ppm}$; $\left\{{ }^{1} \mathrm{H}\right\}{ }^{13} \mathrm{C}$ NMR $\left(500 \mathrm{MHz},\left[\mathrm{D}_{8}\right]\right.$ toluene, $\left.300 \mathrm{~K}\right) \delta 169.6(\mathrm{C}=\mathrm{O})$, 138.9 (C-Ar), 138.7 (C-Ar), 129.5 (CH-Ar), 127.9 (CH-Ar), 125.7 (CH-Ar), 125.0 (CH-Ar), $50.1(\mathrm{NCH}), 45.4(\mathrm{NCH}), 35.4$ $\left(\mathrm{ArCH}_{2}\right), 24.7\left(\mathrm{ArCH}_{2} \mathrm{CH}_{2}\right), 20.4$ (NCMe), 20.2 (NCMe), 20.0 $\left(\mathrm{NCMe}_{2}\right), 14.4\left(\mathrm{ArCH}_{2} \mathrm{CH}_{2} \mathrm{Me}\right) \mathrm{ppm}$.

6-Li/PMDTA: $t$-BuLi $(0.15 \mathrm{~mL}, 1.7 \mathrm{M}$ in pentane, $0.25 \mathrm{mmol})$ was added to a solution of $6-\mathrm{H}(0.07 \mathrm{~g}, 0.25 \mathrm{mmol})$ in toluene/ hexane $(0.5: 0.1 \mathrm{~mL})$ containing freshly distilled $N, N, N^{\prime}, N^{\prime \prime}, N^{\prime \prime}$ pentamethyldiethylenetriamine (PMDTA, $0.05 \mathrm{~mL}, 0.25 \mathrm{mmol}$ ) under nitrogen at $-78{ }^{\circ} \mathrm{C}$. The purple solution which resulted was warmed to room temperature before being stored at $-30{ }^{\circ} \mathrm{C}$ for 3 days to yield red crystals of 6 - $\mathrm{Li}_{l}$ PMDTA. Yield $60 \mathrm{mg}$ (56\%); mp 101-103 ${ }^{\circ} \mathrm{C} ;{ }^{1} \mathrm{H}$ NMR $\left(500 \mathrm{MHz},\left[\mathrm{D}_{8}\right]\right.$ toluene, $273 \mathrm{~K}$, \#1 6-Li $l$ PMDTA major isomer, \#2 6-Li $l$ PMDTA minor isomer, \#3 6-H) $\delta 7.13-7.00(\mathrm{~m}, 0.4 \mathrm{H}, \mathrm{Ar} \# 3), 6.90(\mathrm{ddd}, J(\mathrm{H}, \mathrm{H})$ $=8,7,1 \mathrm{~Hz}, 1 \mathrm{H}, \mathrm{Ar} \# 1), 6.73(\mathrm{dd}, J(\mathrm{H}, \mathrm{H})=8,1 \mathrm{~Hz}, 0.09 \mathrm{H}$,
Ar\#2), $6.69(\mathrm{ddd}, J(\mathrm{H}, \mathrm{H})=9,6,2 \mathrm{~Hz}, 0.09 \mathrm{H}, \mathrm{Ar} \# 2), 6.65(\mathrm{dd}$, $\mathrm{J}(\mathrm{H}, \mathrm{H})=9,1 \mathrm{~Hz}, 0.09 \mathrm{H}, \mathrm{Ar} \# 2), 6.38(\mathrm{dd}, J(\mathrm{H}, \mathrm{H})=8,2 \mathrm{~Hz}, 1 \mathrm{H}$, $\operatorname{Ar} \# 1), 6.36(\mathrm{~d}, J(\mathrm{H}, \mathrm{H})=8 \mathrm{~Hz}, 1 \mathrm{H}, \mathrm{Ar} \# 1), 5.77(\mathrm{ddd}, J(\mathrm{H}, \mathrm{H})=$ $8,6,1 \mathrm{~Hz}, 0.09 \mathrm{H}, \mathrm{Ar} \# 2), 5.58(\mathrm{dd}, J(\mathrm{H}, \mathrm{H})=7,7 \mathrm{~Hz}, 1 \mathrm{H}, \mathrm{Ar} \# 1)$, 4.78 (sept, $\left.{ }^{3} J(\mathrm{H}, \mathrm{H})=6 \mathrm{~Hz}, 0.09 \mathrm{H}, \mathrm{NCH \# 2}\right), 4.3-3.7$ (v br m, $2 \mathrm{H}, \mathrm{NCH} \# 1), 3.55$ (sept, $\left.{ }^{3} J(\mathrm{H}, \mathrm{H})=7 \mathrm{~Hz}, 0.1 \mathrm{H}, \mathrm{NCH} \# 3\right), 3.22$ $\left(\mathrm{dd},{ }^{3} J(\mathrm{H}, \mathrm{H})=6,4 \mathrm{~Hz}, 0.09 \mathrm{H}, \operatorname{ArCH\# 2}\right), 3.10\left(\mathrm{t},{ }^{3} J(\mathrm{H}, \mathrm{H})=6\right.$ $\mathrm{Hz}, 1 \mathrm{H}, \operatorname{ArCH\# 1}), 3.06(\mathrm{~m}, 0.2 \mathrm{H}, \mathrm{NCH \# 2}+\mathrm{NCH \# 3})$, 2.71-2.60 (m, 0.2H, ArCH$\# 3), 2.41\left(\mathrm{~m}, 2 \mathrm{H}, \mathrm{ArCHCH}_{2} \# 1\right)$, 2.25-1.60 (v br m, 9.52H, $\mathrm{CH}_{2}$-PMDTA), $2.08(\mathrm{~s}, 17.85 \mathrm{H}$, Me-PMDTA), 2.02 (v br m, $\sim 0.22 \mathrm{H}, \mathrm{ArCHCH}_{2} \# 2$ or $\left.\mathrm{ArCHCH}_{2} \mathrm{Me \# 2}\right), 1.92-1.80\left(\mathrm{~m}, 0.1 \mathrm{H}, \mathrm{ArCH}_{2} \mathrm{CH}_{2} \# 3\right)$, 1.70-1.58 (m, 0.1H, $\left.\mathrm{ArCH}_{2} \mathrm{CH}_{2} \# 3\right), 1.63\left(\mathrm{~d},{ }^{3} J(\mathrm{H}, \mathrm{H})=5 \mathrm{~Hz}\right.$, $0.3 \mathrm{H}, \mathrm{NCMe} \# 3), 1.62\left(\mathrm{~d},{ }^{3} J(\mathrm{H}, \mathrm{H})=4 \mathrm{~Hz}, 0.3 \mathrm{H}, \mathrm{NCMe} 33\right)$, $1.60\left(\mathrm{~d},{ }^{3} J(\mathrm{H}, \mathrm{H})=7 \mathrm{~Hz}, 0.27 \mathrm{H}, \mathrm{NCMe \# 2}\right), 1.47(\mathrm{v}$ br m, $\approx 0.22 \mathrm{H}, \mathrm{ArCHCH}{ }_{2} \# 2$ or $\left.\mathrm{ArCHCH}_{2} \mathrm{Me} \# 2\right), 1.45\left(\mathrm{~d},{ }^{3} J(\mathrm{H}, \mathrm{H})=7\right.$ $\mathrm{Hz}, 0.27 \mathrm{H}, \mathrm{NCMe} \# 2), 1.44\left(\mathrm{t},{ }^{3} J(\mathrm{H}, \mathrm{H})=6 \mathrm{~Hz}, 3 \mathrm{H}\right.$, $\mathrm{ArCHCH}_{2} \mathrm{Me \# 1}$ ), 1.32-1.10 (br m, 12H, NCMe\#1), 1.06 (d, $\left.{ }^{3} J(\mathrm{H}, \mathrm{H})=6 \mathrm{~Hz}, 0.27 \mathrm{H}, \mathrm{NCMe \# 2}\right), 0.98\left(\mathrm{t},{ }^{3} J(\mathrm{H}, \mathrm{H})=7 \mathrm{~Hz}\right.$, $\left.0.3 \mathrm{H}, \mathrm{ArCH}_{2} \mathrm{CH}_{2} \mathrm{Me \# 3}\right), 0.84\left(\mathrm{~d},{ }^{3} J(\mathrm{H}, \mathrm{H})=7 \mathrm{~Hz}, 0.27 \mathrm{H}\right.$, $\mathrm{NCMe} \# 2), 0.73\left(\mathrm{~d},{ }^{3} J(\mathrm{H}, \mathrm{H})=7 \mathrm{~Hz}, 0.3 \mathrm{H}, \mathrm{NCMe} \# 3\right), 0.72$ (d, $\left.{ }^{3} J(\mathrm{H}, \mathrm{H})=7 \mathrm{~Hz}, 0.3 \mathrm{H}, \mathrm{NCMe} \# 3\right) \mathrm{ppm} ;\left\{{ }^{1} \mathrm{H}\right\}{ }^{13} \mathrm{C}$ NMR $(125$ $\mathrm{MHz},\left[\mathrm{D}_{8}\right]$ toluene, $273 \mathrm{~K}$, \#1 6-Li ${ }_{l}$ PMDTA major isomer, \#2 6-Li $l_{l}$ PMDTA minor isomer, \#3 6-H) $\delta 179.4(\mathrm{C}=\mathrm{O} \# 1), 177.4$ $(\mathrm{C}=\mathrm{O} \# 2), 169.5(\mathrm{C}=\mathrm{O} \# 3), 146.6(\mathrm{C}-\mathrm{Ar} \# 2), 144.7(\mathrm{C}-\mathrm{Ar} \# 1)$, 138.9 (C-Ar\#3), 138.7 (C-Ar\#3), 130.1 (CH-Ar\#2), 130.0 (CHAr\#1), 129.4 (CH-Ar\#3), 127.8 (CH-Ar\#3), 127.0 (CH-Ar\#1), 126.7 (CH-Ar\#2), 125.6 (CH-Ar\#3), 124.9 (CH-Ar\#3), 123.1 (CH-Ar\#2), 113.9 (C-Ar\#1), 112.0 (CH-Ar\#1), 108.8 (C-Ar\#2), 99.9 (CH-Ar\#2), 96.3 (CH-Ar\#1), 71.9 (ArCH\#2), 67.1 (ArCH\#1), 57.1 ( $\mathrm{CH}_{2}$-PMDTA), 53.8 ( $\mathrm{CH}_{2}$-PMDTA), 51.2 (NCH\#1), 50.0 (NCH\#3), 45.3 (NCH\#3), 45.0 (Me-PMDTA), 43.8 (Me-PMDTA), $35.3\left(\mathrm{ArCH}_{2} \# 3\right), 26.3\left(\mathrm{ArCHCH}_{2} \# 2\right), 24.5$ ( $\left.\mathrm{ArCH} 2 \mathrm{CH}_{2} \# 3\right), 22.6\left(\mathrm{ArCHCH}_{2} \# 1\right), 22.5$ (NCMe\#2), 21.2 (NCMe\#1), 21.0 (NCMe\#1), 20.4 (NCMe\#3), 20.2 (NCMe\#3), 20.0 ( $\mathrm{NCMe \# 3),} 17.4$ ( $\mathrm{ArCHCH}_{2} \mathrm{Me \# 2),} 16.8$ $\left(\mathrm{ArCHCH}_{2} \mathrm{Me \# 1}\right), 14.2\left(\mathrm{ArCH}_{2} \mathrm{CH}_{2} \mathrm{Me} \# 3\right) \mathrm{ppm} ;{ }^{7} \mathrm{Li} \mathrm{NMR}(194$ $\mathrm{MHz},\left[\mathrm{D}_{8}\right]$ toluene, $273 \mathrm{~K}$, \#1 6-Li $l$ PMDTA major isomer, \#2 6-Li $l_{l}$ PMDTA minor isomer) $\delta 0.51(\mathrm{~s}, \# 1), 0.15$ (s, \#2) ppm; anal. calcd for $\mathrm{C}_{25} \mathrm{H}_{47} \mathrm{LiN}_{4} \mathrm{O}$ : C, 70.38; H, 11.10; N, 13.13; found: $\mathrm{C}, 70.34 ; \mathrm{H}, 10.83 ; \mathrm{N}, 12.33$; crystal data for 6-Li·PMDTA: $\mathrm{C}_{25} \mathrm{H}_{47} \mathrm{LiN}_{4} \mathrm{O}, M=426.61$, monoclinic, space group $P 2{ }_{1} / n, a=9.6194(2), b=29.1721(8), c=10.0296(3) \AA, \beta$ $=102.643(2)^{\circ}, V=2746.24(13) \AA^{3}, Z=4, \rho_{\text {calcd }}=1.032 \mathrm{~g}$ $\mathrm{cm}^{-3}$; Mo K $\alpha$ radiation, $\lambda=0.71070 \AA, \mu=0.063 \mathrm{~mm}^{-1}, T=$ $180 \mathrm{~K} ; 14239$ data (4461 unique, $R_{\text {int }}=0.0477, \theta<24.40^{\circ}$ ) were collected on a Nonius Kappa CCD diffractometer. Structure solved by direct methods and refined by full-matrix leastsquares on $F^{2}$ values of all data giving $w R 2=\left\{\Sigma\left[w\left(F_{\mathrm{o}}{ }^{2}-F_{\mathrm{c}}{ }^{2}\right)^{2}\right] /\right.$ $\left.\Sigma\left[w\left(F_{\mathrm{o}}{ }^{2}\right)^{2}\right]\right\}^{1 / 2}=0.1261$, conventional $R=0.0493$ for $F$ values of 2591 reflections with $F_{\mathrm{o}}{ }^{2}>2 \sigma\left(F_{\mathrm{o}}{ }^{2}\right), G o F=0.976$ for 310 
parameters. Residual electron density extrema 0.159 and -0.141 $\mathrm{e} \AA^{-3}$.

6-Li $l$ DGME: $t$-BuLi $(0.15 \mathrm{~mL}, 1.7 \mathrm{M}$ in pentane, $0.25 \mathrm{mmol})$ was added to a solution of $6-\mathrm{H}(0.07 \mathrm{~g}, 0.25 \mathrm{mmol})$ in toluene/ hexane $(0.3: 0.1 \mathrm{~mL})$ containing diglyme (DGME, $0.04 \mathrm{~mL}$, $0.25 \mathrm{mmol}$ ) under nitrogen at $-78^{\circ} \mathrm{C}$. The resulting purple solution was warmed to room temperature and stored at $-30{ }^{\circ} \mathrm{C}$ for 3 days to yield red crystals of 6-Li $l^{-}$DGME. Yield $44 \mathrm{mg}(45 \%)$ $\mathrm{mp}<25{ }^{\circ} \mathrm{C} ;{ }^{1} \mathrm{H}$ NMR $\left(500 \mathrm{MHz},\left[\mathrm{D}_{8}\right]\right.$ toluene, $253 \mathrm{~K}$, \#1 6-Li $l$ DGME major isomer, \#2 6-Li $l_{l}$ DGME minor isomer, \#3 6-H) $\delta$ 7.13-7.00 (m, 12H, Ar\#3), $6.88\left(\mathrm{dd},{ }^{3} J(\mathrm{H}, \mathrm{H})=7,8 \mathrm{~Hz}\right.$, $1 \mathrm{H}, \mathrm{Ar} \# 1), 6.74\left(\mathrm{~d},{ }^{3} J(\mathrm{H}, \mathrm{H})=8 \mathrm{~Hz}, 0.15 \mathrm{H}, \mathrm{Ar} \# 2\right), 6.63(\mathrm{~m}$, $0.3 \mathrm{H}, \operatorname{Ar} \# 2), 6.46\left(\mathrm{~d},{ }^{3} J(\mathrm{H}, \mathrm{H})=7 \mathrm{~Hz}, 1 \mathrm{H}, \operatorname{Ar} \# 1\right), 6.38(\mathrm{~d}$, $\left.{ }^{3} J(\mathrm{H}, \mathrm{H})=9 \mathrm{~Hz}, 1 \mathrm{H}, \mathrm{Ar} \# 1\right), 5.69(\mathrm{~m}, 0.15 \mathrm{H}, \mathrm{Ar} \# 2), 5.63(\mathrm{dd}$, $\left.{ }^{3} J(\mathrm{H}, \mathrm{H})=6,7 \mathrm{~Hz}, 1 \mathrm{H}, \mathrm{Ar} \# 1\right), 4.4-3.6(\mathrm{v}$ br m, 2H, NCH\#1), $3.54(\mathrm{~m}, 3 \mathrm{H}, \mathrm{NCH} \# 3), 3.39\left(\mathrm{t},{ }^{3} J(\mathrm{H}, \mathrm{H})=4 \mathrm{~Hz}, 16 \mathrm{H}, \mathrm{CH}_{2}-\right.$ DGME), $3.27\left(\mathrm{t},{ }^{3} J(\mathrm{H}, \mathrm{H})=5 \mathrm{~Hz}, 16 \mathrm{H}, \mathrm{CH}_{2}-\mathrm{DGME}\right), 3.15(\mathrm{~s}$, 24H, Me-DGME), 3.08 (m, 3H, NCH\#3), $3.05(\mathrm{~m}, 1 \mathrm{H}$, $\mathrm{ArCH \# 1}), 2.69-2.58\left(\mathrm{~m}, 6 \mathrm{H}, \mathrm{ArCH}_{2} \# 3\right), 2.35(\mathrm{~m}, 2 \mathrm{H}$, $\left.\mathrm{ArCHCH}_{2} \# 1\right), 1.79\left(\mathrm{~m}, 3 \mathrm{H}, \mathrm{ArCH}_{2} \mathrm{CH}_{2} \# 3\right), 1.62(\mathrm{~m}, 3 \mathrm{H}$, $\left.\mathrm{ArCH}_{2} \mathrm{CH}_{2} \# 3\right), 1.61\left(\mathrm{~d},{ }^{3} \mathrm{~J}(\mathrm{H}, \mathrm{H})=7 \mathrm{~Hz}, 9 \mathrm{H}, \mathrm{NCMe} 33\right), 1.60$ $\left(\mathrm{d},{ }^{3} J(\mathrm{H}, \mathrm{H})=7 \mathrm{~Hz}, 9 \mathrm{H}, \mathrm{NCMe} \# 3\right), 1.36\left(\mathrm{t},{ }^{3} J(\mathrm{H}, \mathrm{H})=7 \mathrm{~Hz}, 3 \mathrm{H}\right.$, $\mathrm{ArCHCH}_{2} \mathrm{Me \# 1}$ ), 1.24 (br m, 6H, NCMe\#1), 1.13 (br m, 6H, $\mathrm{NCMe \# 1}), 0.97\left(\mathrm{t},{ }^{3} J(\mathrm{H}, \mathrm{H})=7 \mathrm{~Hz}, 9 \mathrm{H}, \mathrm{ArCH}_{2} \mathrm{CH}_{2} \mathrm{Me \# 3}\right), 0.73$ $\left(\mathrm{d},{ }^{3} J(\mathrm{H}, \mathrm{H})=7 \mathrm{~Hz}, 18 \mathrm{H}, \mathrm{NCMe} \# 3\right) \mathrm{ppm} ;\left\{{ }^{1} \mathrm{H}\right\}{ }^{13} \mathrm{C}$ NMR $(125$ $\mathrm{MHz}$, [D8]toluene, $273 \mathrm{~K}$, \#1 6-Li ? DGME major isomer, \#2 6-Lil ${ }_{l}$ DGME minor isomer, \#3 6-H) $\delta 179.5(\mathrm{C}=\mathrm{O} \# 1), 177.2$ $(\mathrm{C}=\mathrm{O} \# 2), 169.6(\mathrm{C}=\mathrm{O} \# 3), 145.9(\mathrm{C}-\mathrm{Ar} \# 1), 138.7(\mathrm{C}-\mathrm{Ar} \# 3)$, 138.6 (C-Ar\#3), 137.5 (C-Ar\#1), 130.8 (CH-Ar\#2), 130.1 (CHAr\#1), 129.4 (CH-Ar\#3), 127.8 (CH-Ar\#3), 127.1 (CH-Ar\#1), 126.5 (CH-Ar\#2), 125.6 (CH-Ar\#3), 125.0 (CH-Ar\#3), 122.6 (CH-Ar\#2), 112.4 (CH-Ar\#1), 99.2 (C-Ar\#2), 97.6 (CH-Ar\#1), 71.5 ( $\mathrm{CH}_{2}$-DGME), 70.1 ( $\mathrm{CH}_{2}$-DGME), 64.6 (ArCH\#1), 58.4 (Me-DGME), 50.1 (NCH\#3), 45.4 ( $\mathrm{NCH \# 2),} 35.3$ ( $\left.\mathrm{ArCH}_{2} \# 3\right)$, $24.4\left(\mathrm{ArCH}_{2} \mathrm{CH}_{2} \# 3\right), 22.3\left(\mathrm{ArCHCH}_{2} \# 1\right), 20.4$ ( $\mathrm{NCMe \# 3),}$ 20.2 (NCMe\#3), 20.0 ( $\left.\mathrm{NCMe}_{2} \# 3\right), 16.6\left(\mathrm{ArCHCH}_{2} \mathrm{Me \# 1}\right), 14.2$ $\left(\mathrm{ArCH}_{2} \mathrm{CH}_{2} \mathrm{Me \# 3}\right) \mathrm{ppm} ;{ }^{7} \mathrm{Li} \mathrm{NMR}$ spectroscopy (194 MHz, $\left[\mathrm{D}_{8}\right]$ toluene, $273 \mathrm{~K}$, \#1 6-Li $l$ DGME major isomer, \#2 6-Li $l$ DGME minor isomer) $\delta 0.62(\mathrm{~s}, \# 2), 0.26$ (s, \#1) ppm; anal. calcd for $\mathrm{C}_{22} \mathrm{H}_{38} \mathrm{LiNO}_{4}$ : C, 68.19; H, 9.88; N, 3.61; found: C, 68.00; H, 9.62; N, 4.12; crystal data for 6-Li $l$ DGME: $\mathrm{C}_{22} \mathrm{H}_{38} \mathrm{LiNO}_{4}, M=387.47$, monoclinic, space group $P 2_{1} / n, a=$ 7.8821(16), $b=18.975(4), c=15.737(3) \AA, \beta=92.84(3)^{\circ}, V=$ $2350.8(8) \AA^{3}, Z=4, \rho_{\text {calcd }}=1.095 \mathrm{~g} \mathrm{~cm}^{-3}$; Mo Ka radiation, $\lambda=$ $0.71073 \AA, \mu=0.073 \mathrm{~mm}^{-1}, T=173 \mathrm{~K} .13765$ data $(4238$ unique, $R_{\text {int }}=0.0425, \theta<25.31^{\circ}$ ) were collected on a Nonius Kappa CCD diffractometer. The structure was solved by direct methods and refined by full-matrix least-squares on $F^{2}$ values of all data to give $w R 2=\left\{\Sigma\left[w\left(F_{\mathrm{o}}{ }^{2}-F_{\mathrm{c}}{ }^{2}\right)^{2}\right] / \Sigma\left[w\left(F_{\mathrm{o}}{ }^{2}\right)^{2}\right]\right\}^{1 / 2}=$ 0.2729 , conventional $R=0.0938$ for $F$ values of 2961 reflec- tions with $F_{\mathrm{o}}{ }^{2}>2 \sigma\left({F_{\mathrm{o}}}^{2}\right), G o F=1.040$ for 253 parameters. Residual electron density extrema 0.729 and $-0.616 \mathrm{e}^{-3}$.

\section{Computational details}

Geometry optimisation of cis/trans-6-Li $l^{\cdot} \mathrm{L}(\mathrm{L}=$ PMDTA, DGME) was carried out using the B3LYP density functional and a $6-311++\mathrm{G}(2 \mathrm{~d}, 2 \mathrm{p}$ ) basis and Gaussian 09 (see Supporting Information File 3). To give free energy differences relevant to the solid state, thermodynamic corrections (at the B3LYP/6$311 \mathrm{G}(2 \mathrm{~d}, 2 \mathrm{p})$ level) and condensed phase effects, using the CPCM model (at the B3LYP/6-311++G(2df,2dp) level) with a dielectric constant of 2.37 , were included.

\section{Supporting Information}

\section{Supporting Information File 1}

Crystallographic data for 1-Li·PMDTA.

[http://www.beilstein-journals.org/bjoc/content/

supplementary/1860-5397-8-5-S1.cif]

\section{Supporting Information File 2}

Crystallographic data for 1-Li·DGME.

[http://www.beilstein-journals.org/bjoc/content/

supplementary/1860-5397-8-5-S2.cif]

\section{Supporting Information File 3}

NMR spectroscopic data and DFT calculations for $\mathbf{6}-\mathrm{Li} / \mathrm{L}$

(L = PMDTA, DGME).

[http://www.beilstein-journals.org/bjoc/content/ supplementary/1860-5397-8-5-S3.pdf]

\section{Acknowledgements}

The authors thank the UK EPSRC (EP/G000816/1) and the University of Cambridge for financial support.

\section{References}

1. Clayden, J. Organolithiums: Selectivity for Synthesis; Pergamon: Oxford, 2002.

2. Gschwend, H. W.; Rodriguez, H. R. Hetero-Facilitated Lithiations; Organic Reactions, Vol. 26; Wiley: New York, 1979; pp 1-360. doi:10.1002/0471264180.or026.01

3. Snieckus, V. Chem. Rev. 1990, 90, 879-933. doi:10.1021/cr00104a001

4. Clark, R. D.; Jahangir, A. Lateral Lithiation Reactions Promoted by Heteroatomic Substituents; Organic Reactions, Vol. 47; Wiley: New York, 1995; pp 1-314. doi:10.1002/0471264180.or047.01

5. Maggi, R.; Schlosser, M. J. Org. Chem. 1996, 61, 5430-5434. doi:10.1021/jo9604550

6. Hartung, C. G.; Snieckus, V. The Directed ortho Metalation Reaction A Point of Departure for New Synthetic Aromatic Chemistry. In Modern Arene Chemistry; Astruc, D., Ed.; Wiley-VCH: Weinheim, Germany, 2002; pp 330-367. doi:10.1002/3527601767.ch10 
7. Clayden, J. In Chemistry of Organolithium Compounds; Rapport, Z.; Marek, I., Eds.; Wiley: Chichester, 2004; Vol. 1, pp 495-646.

8. Whisler, M. C.; MacNeil, M.; Snieckus, V.; Beak, P. Angew. Chem., Int. Ed. 2004, 43, 2206-2225. doi:10.1002/anie.200300590

9. Macklin, T.; Snieckus, V. In Handbook of C-H Transformations; Dyker, G., Ed.; Wiley-VCH: Weinheim: Germany, 2005; pp 106-118.

10. Clayden, J.; Stimson, C. C.; Keenan, M. Chem. Commun. 2006, 1393-1394. doi:10.1039/b600181e

11. Miller, R. E.; Rantanen, T.; Ogilvie, K. A.; Groth, U.; Snieckus, V. Org. Lett. 2010, 12, 2198-2201. doi:10.1021/ol100493v

12. Wang, W.; Snieckus, V. J. Org. Chem. 1992, 57, 424-426. doi:10.1021/jo00028a004

13. Kalinin, A. V.; Reed, M. A.; Norman, B. H.; Snieckus, V. J. Org. Chem. 2003, 68, 5992-5999. doi:10.1021/jo034325k

14. Cai, X.; Snieckus, V. Org. Lett. 2004, 6, 2293-2295. doi:10.1021/ol049780x

15. James, C. A.; Snieckus, V. J. Org. Chem. 2009, 74, 4080-4093. doi:10.1021/jo9001454

16. Beak, P.; Tse, A.; Hawkins, J.; Chen, C.-W.; Mills, S. Tetrahedron 1983, 39, 1983-1989. doi:10.1016/S0040-4020(01)91916-7

17. Court, J. J.; Hlasta, D. J. Tetrahedron Lett. 1996, 37, 1335-1338. doi:10.1016/0040-4039(96)00016-0

18. Comins, D. L.; Brown, J. D. J. Org. Chem. 1986, 51, 3566-3572. doi:10.1021/jo00369a002

19. Clark, R. D.; Jahangir; Langston, J. A. Can. J. Chem. 1994, 72, 23-30. doi:10.1139/v94-005

20. Campbell Smith, A.; Donnard, M.; Haywood, J.; McPartlin, M.; Vincent, M. A.; Hillier, I. H.; Clayden, J.; Wheatley, A. E. H. Chem.-Eur. J. 2011, 17, 8078-8084. doi:10.1002/chem.201100240

21. Clayden, J.; Davies, R. P.; Hendy, M. A.; Snaith, R.; Wheatley, A. E. H. Angew. Chem., Int. Ed. 2001, 40, 1238-1240. doi:10.1002/1521-3773(20010401)40:7<1238::AID-ANIE1238>3.0.CO; 2-G

22. Bond, A. D.; Clayden, J.; Wheatley, A. E. H. Acta Crystallogr., Sect. E 2001, 57, o292-o294. doi:10.1107/S1600536801003580

23. Armstrong, D. R.; Boss, S. R.; Clayden, J.; Haigh, R.; Kirmani, B. A.; Linton, D. J.; Schooler, P.; Wheatley, A. E. H. Angew. Chem., Int. Ed. 2004, 43, 2135-2138. doi:10.1002/anie.200353324

24. Armstrong, D. R.; Clayden, J.; Haigh, R.; Linton, D. J.; Schooler, P.; Wheatley, A. E. H. Chem. Commun. 2003, 1694-1695. doi:10.1039/b302283h

25. Clayden, J.; Pink, J. H.; Westlund, N.; Frampton, C. S. J. Chem. Soc., Perkin Trans. 1 2002, 901-917. doi:10.1039/B200358A

26. Clayden, J.; McCarthy, C.; Helliwell, M. Chem. Commun. 1999, 2059-2060. doi:10.1039/a906398f

27. Ahmed, A.; Bragg, R. A.; Clayden, J.; Lai, L. W.; McCarthy, C.; Pink, J. H.; Westlund, N.; Yasin, S. A. Tetrahedron 1998, 54, 13277-13294. doi:10.1016/S0040-4020(98)00814-X

28. Clayden, J.; Johnson, P.; Pink, J. H.; Helliwell, M. J. Org. Chem. 2000, 65, 7033-7040. doi:10.1021/jo0007074

29. Sheldrick, G. M. Acta Crystallogr., Sect. A 1990, 46, 467-473. doi:10.1107/S0108767390000277

30. SHELXL-97 Program for Crystal Structure Refinement; University of Göttingen: Göttingen, Germany, 1997.

31. Patterman, S. P.; Karle, I. L.; Stucky, G. D. J. Am. Chem. Soc. 1970, 92, 1150-1157. doi:10.1021/ja00708a008

32. Brooks, J. J.; Stucky, G. D. J. Am. Chem. Soc. 1972, 94, 7333-7338. doi:10.1021/ja00776a012
33. Olmstead, M. M.; Power, P. P. J. Am. Chem. Soc. 1985, 107, 2174-2175. doi:10.1021/ja00293a059

34. Beno, M. A.; Hope, H.; Olmstead, M. M.; Power, P. P. Organometallics 1985, 4, 2117-2121. doi:10.1021/om00131a009

35. Bartlett, R. A.; Dias, H. V. R.; Power, P. P. J. Organomet. Chem. 1988, 341, 1-9. doi:10.1016/0022-328X(88)89058-2

36. Engelhardt, L. M.; Leung, W.-P.; Raston, C. L.; Salem, G.; Twiss, P.; White, A. H. J. Chem. Soc., Dalton Trans. 1988, 2403-2409. doi:10.1039/DT9880002403

37. Zarges, W.; Marsch, M.; Harms, K.; Boche, G. Chem. Ber. 1989, 122, 2303-2309. doi:10.1002/cber.19891221217

38. Bock, H.; Ruppert, K.; Havlas, Z.; Bensch, W.; Hönle, W.; von Schnering, H. G. Angew. Chem., Int. Ed. Engl. 1991, 30, 1183-1186. doi:10.1002/anie.199111831

39. Harder, S.; Lutz, M. Organometallics 1994, 13, 5173-5176. doi:10.1021/om00024a072

40. Wijkens, P.; van Koten, E. M.; Janssen, M. D.; Jastrzebski, J. T. B. H.; Spek, A. L.; van Koten, G. Angew. Chem., Int. Ed. Engl. 1995, 34, 219-222. doi:10.1002/anie.199502191

41. Arnold, J.; Knapp, V.; Schmidt, J. A. R.; Shafir, A. J. Chem. Soc., Dalton Trans. 2002, 3273-3274. doi:10.1039/B205792C

42. Fernández, I.; Martínez-Vivente, E.; Breher, F.; Pregosin, P. S. Chem.-Eur. J. 2005, 11, 1495-1506. doi:10.1002/chem.200400867

43. Fraenkel, G.; Chen, X.; Gallucci, J.; Ren, Y. J. Am. Chem. Soc. 2008, 130, 4140-4145. doi:10.1021/ja0765215

44. Boche, G.; Marsch, M.; Harbach, J.; Harms, K.; Ledig, B.; Schubert, F.; Lohrenz, J. C. W.; Ahlbrecht, H. Chem. Ber. 1993, 126, 1887-1894. doi:10.1002/cber.19931260820

45. Clegg, W.; Izod, K.; McFarlane, W.; O'Shaughnessy, P. Organometallics 1999, 18, 3950-3952. doi:10.1021/om9904910

46. Gauvin, R. M.; Kyritsakas, N.; Fischer, J.; Kress, J. Chem. Commun. 2000, 965-966. doi:10.1039/b002004o

47. Winkler, M.; Lutz, M.; Müller, G. Angew. Chem., Int. Ed. Engl. 1994, 33, 2279-2281. doi:10.1002/anie.199422791

48. Bailey, P. J.; Barrett, T.; Parsons, S. J. Organomet. Chem. 2001, 625, 236-244. doi:10.1016/S0022-328X(01)00674-X

49. Müller, G.; Abicht, H.-P.; Waldkircher, M.; Lachmann, J.; Lutz, M.; Winkler, M. J. Organomet. Chem. 2001, 622, 121-134. doi:10.1016/S0022-328X(00)00885-8

50. Zarges, W.; Marsch, M.; Harms, K.; Koch, W.; Frenking, G.; Boche, G. Chem. Ber. 1991, 124, 543-549. doi:10.1002/cber.19911240321

51. Müller, J. F. K.; Neuburger, M.; Spingler, B. Angew. Chem., Int. Ed. 1999, 38, 3549-3552. doi:10.1002/(SICI)1521-3773(19991203)38:23<3549::AID-ANIE3549>3 .0.CO;2-D

52. Lennartson, A.; Sundberg, J.; Wiklund, T.; Hilmersson, G.; Håkansson, M. Eur. J. Inorg. Chem. 2010, 3029-3039. doi:10.1002/ejic.200901172

53. Meyer, J. T. E.; Schulz, T.; Pandey, S. K.; Stalke, D. Inorg. Chem. 2010, 49, 2743-2749. doi:10.1021/ic902071m

54. Byrne, L. T.; Engelhardt, L. M.; Jacobsen, G. E.; Leung, W.-P.; Papasergio, R. I.; Raston, C. L.; Skelton, B. W.; Twiss, P.; White, A. H. J. Chem. Soc., Dalton Trans. 1989, 105-113. doi:10.1039/DT9890000105

55. Feil, F.; Harder, S. Organometallics 2001, 20, 4616-4622. doi:10.1021/om010444j

56. Hill, M. S.; Hitchcock, P. B. Organometallics 2002, 21, 220-225. doi:10.1021/om010716i 
57. Strohmann, C.; Lehmen, K.; Wild, K.; Schildbach, D. Organometallics 2002, 21, 3079-3081. doi:10.1021/om0201664

58. Shi, H.-P.; Liu, D.-S.; Huang, S.-P.

Acta Crystallogr., Sect. E: Struct. Rep. Online 2003, 59, m319-m321. doi:10.1107/S1600536803008997

59. Strohmann, C.; Buchold, D. H. M.; Seibel, T.; Wild, K.; Schildbach, D. Eur. J. Inorg. Chem. 2003, 3453-3463. doi:10.1002/ejic.200300323

60. Shi, H.-P.; Liu, D.-S.; Huang, S.-P.

Acta Crystallogr., Sect. C: Cryst. Struct. Commun. 2004, 60, m107-m109. doi:10.1107/S0108270104000836

61. Schumann, H.; Freckmann, D. M. M.; Dechert, S. Z. Anorg. Allg. Chem. 2008, 634, 1334-1338. doi:10.1002/zaac.200800067

62. Ott, H.; Däschlein, C.; Leusser, D.; Schildbach, D.; Seibel, T.; Stalke, D.; Strohmann, C. J. Am. Chem. Soc. 2008, 130, 11901-11911. doi:10.1021/ja711104q

63. Wang, Z.-X.; Qi, C.-Y. Dalton Trans. 2005, 996-1001. doi:10.1039/b418389d

64. Clayden, J.; Stimson, C. C.; Keenan, M.; Wheatley, A. E. H. Chem. Commun. 2004, 228-229. doi:10.1039/b310963a

65. Rinaldi, P. L. J. Am. Chem. Soc. 1983, 105, 5167-5168. doi:10.1021/ja00353a071

66. Neuhaus, D.; Williams, M. The Nuclear Overhauser Effect in Structural and Coformational Analysis; VCH Publishers (UK): Cambridge, 1989. (Chapter 10 and references cited therein).

67. Berg, U.; Liljefors, T.; Roussel, C.; Sandström, J. Acc. Chem. Res. 1985, 18, 80-86. doi:10.1021/ar00111a003

68. Kottke, T.; Stalke, D. J. Appl. Crystallogr. 1993, 26, 615-619. doi:10.1107/S0021889893002018

\section{License and Terms}

This is an Open Access article under the terms of the Creative Commons Attribution License (http://creativecommons.org/licenses/by/2.0), which permits unrestricted use, distribution, and reproduction in any medium, provided the original work is properly cited.

The license is subject to the Beilstein Journal of Organic Chemistry terms and conditions:

(http://www.beilstein-journals.org/bjoc)

The definitive version of this article is the electronic one which can be found at: doi:10.3762/bjoc. 8.5 